\title{
Protein Kinase C Is Activated in Glomeruli from Streptozotocin Diabetic Rats Possible Mediation by Glucose
}

Patricia A. Craven and Frederick R. DeRubertis

Department of Medicine, Veterans Administration Medical Center and University of Pittsburgh, Pittsburgh, Pennsylvania 15240

\begin{abstract}
Glomerular inositol content and the turnover of polyphosphoinositides was reduced by $58 \%$ in 1-2 wk streptozotocin diabetic rats. Addition of inositol to the incubation medium increased polyphosphoinositide turnover in glomeruli from diabetic rats to control values. Despite the reduction in inositol content and polyphosphoinositide turnover, protein kinase $\mathbf{C}$ was activated in glomeruli from diabetic rats, as assessed by an increase in the percentage of enzyme activity associated with the particulate cell fraction. Total protein kinase $C$ activity was not different between glomeruli from control and diabetic rats. Treatment of diabetic rats with insulin to achieve near euglycemia prevented the increase in particulate protein kinase $C$. Moreover, incubation of glomeruli from control rats with glucose $(100-1,000 \mathrm{mg} / \mathrm{dl})$ resulted in a progressive increase in labeled diacylglycerol production and in the percentage of protein kinase $C$ activity which was associated with the particulate fraction. These results support a role for hyperglycemia per se in the enhanced state of activation of protein kinase $C$ seen in glomeruli from diabetic rats. Glucose did not appear to increase diacylglycerol by stimulating inositol phospholipid hydrolysis in glomeruli. Other pathways for diacylglycerol production, including de novo synthesis and phospholipase $\mathbf{C}$ mediated hydrolysis of phosphatidylcholine or phosphatidylinositol-glycan are not excluded.
\end{abstract}

\section{Introduction}

Previous studies have suggested that many of the complications of diabetes may be related to enhanced polyol pathway activity. In diabetic nerve (1-4), lens (1-4), and renal glomeruli (4-8) sorbitol has been reported to be markedly elevated and inositol content reduced. Moreover, treatment of diabetic rats with sorbinil, an inhibitor of aldose reductase activity, prevents cataract formation (9), increases nerve conduction velocity (10), reduces hyperfiltration (8), and may prevent the development of nephropathy $(6,7)$. Recently it has been proposed that a reduced state of activation of protein kinase $C(2$, 11) may be a common feature of tissues which exhibit enhanced polyol pathway activity and reduced inositol content as a consequence of diabetes. In this proposed schema (2), reduced tissue myo-inositol leads to reduced inositol phospholipid content and/or turnover, with a resultant reduced generation of diacylglycerol, an endogenous activator of protein ki-

Address reprint requests to Dr. F. R. DeRubertis, Veterans Administration Medical Center, University Drive C, Pittsburgh, PA 15240.

Received for publication 27 June 1988 and in revised form $10 \mathrm{No}$ vember 1988.

The Journal of Clinical Investigation, Inc.

Volume 83, May 1989, 1667-1675 nase C. Impaired diacylglycerol availability in turn could lead to the impaired activation of protein kinase $\mathrm{C}$. It has been speculated that reduced protein kinase $\mathrm{C}$ activity may contribute to the development of diabetic complications including nephropathy (2). Some (12) but not all $(13,14)$ studies support this notion. With respect to the renal glomerulus, inositol content was reported to be reduced in the streptozotocin diabetic rat (5). However, the impact of reduced inositol content on inositol phospholipid turnover and the state of activation of protein kinase $\mathrm{C}$ in glomeruli has not been examined. Accordingly, in the present study we examined $(a)$ inositol content; $(b)$ the turnover of labeled inositol phospholipids; and $(c)$ the state of activation of protein kinase $\mathrm{C}$ in glomeruli isolated from rat kidneys 1-2 wk after induction of diabetes with streptozotocin. The results demonstrate that protein kinase $C$ is activated in glomeruli from diabetic rats despite a reduction in glomerular inositol content and the turnover of polyphosphoinositides. Studies in vitro suggest that activation of glomerular protein kinase $C$ in diabetes may be mediated at least in part by glucose.

\section{Methods}

Treatment of rats. Female Sprague-Dawley rats (Zivic-Miller, Pittsburgh, PA) were weighed and placed in one of four groups. The number of rats in each group is indicated separately below for each parameter measured. Controls received $1 \mathrm{ml} / \mathrm{kg}$ body wt sterile $0.01 \mathrm{M}$ citric acid, $0.09 \%$ saline, $\mathrm{pH} 4$, by tail vein. The diabetic rats received 60 $\mathrm{mg} / \mathrm{kg}$ body wt sterile streptozotocin $(60 \mathrm{mg} / \mathrm{ml}$ in $0.01 \mathrm{M}$ citric acid, $0.09 \%$ saline, $\mathrm{pH} 4$ ) by tail vein. Where indicated, insulin treated diabetic rats received $10 \mathrm{U} / \mathrm{kg}$ per $\mathrm{d}$ of regular Iletin II pork insulin (Eli Lilly \& Co., Indianapolis, IN) by osmotic minipump (2002; Alzet Corp., Palo Alto, CA) as previously described (15). Minipumps were implanted intraperitoneally $24 \mathrm{~h}$ after streptozotocin injection. All rats were allowed food and water ad lib. and were studied 1-2 wk after injection of vehicle or streptozotocin. Sorbinil treated diabetic rats received $20 \mathrm{mg} / \mathrm{kg}$ per $\mathrm{d}$ in the diet beginning the day before streptozotocin injection as previously reported (15). At death, blood was drawn from the abdominal aorta for determination of nonfasting plasma glucose by the glucose oxidase method (16).

Preparation of glomeruli. Rats were anesthetized with pentobarbital $(5 \mathrm{mg} / 100 \mathrm{~g})$ and the abdominal aorta exposed through a midline incision. An intravenous catheter (20 gauge) was inserted into the abdominal aorta below the renal arteries. A $20-\mathrm{ml}$ syringe was attached to the catheter and the kidneys were perfused for 20-30 s with 20-30 $\mathrm{ml}$ of Krebs-Ringer bicarbonate buffer containing $1 \mathrm{mg} / \mathrm{ml}$ glucose $(\mathrm{KRBG})^{1}$ that had been previously equilibrated with $95 \% \mathrm{O}_{2}, 5 \% \mathrm{CO}_{2}$. Glomeruli were prepared by graded sieving as previously described (17). The final suspension was composed of $>95 \%$ glomeruli as as-

1. Abbreviations used in this paper: $\mathrm{IP}$, inositol-1-phosphate; $\mathrm{IP}_{2}$, inositol-1,4-biphosphate; $\mathrm{IP}_{3}$, inositol-1,4,5-trisphosphate; KRBG, KrebsRinger bicarbonate buffer with glucose; OAG, 1-oleoyl 2-acetyl glycerol; PIP, phosphatidylinositol-4-phosphate; PIP $_{2}$, phosphatidylinositol-4,5-bisphosphate. 
sessed by light microscopy. The viability of the isolated glomeruli was $\mathbf{9 5 \%}$ or greater as determined by trypan blue exclusion.

Extraction of glomerular lipids. Glomeruli were suspended in 0.55 $\mathrm{ml}$ of $\mathrm{H}_{2} \mathrm{O}$ and extracted with $250 \mu \mathrm{l} 0.1 \mathrm{M} \mathrm{Na}{ }_{2}$ EDTA, $2 \mathrm{M} \mathrm{KCl}, 2.5$ $\mathrm{ml}$ methanol and $1 \mathrm{ml} \mathrm{CHCl}$ as described by Cohen et al. (18). If ${ }^{32} \mathrm{P}$ incorporation into phospholipids was to be assessed, ${ }^{14} \mathrm{C}$ Labeled phosphatidylinositol, phosphatidylcholine, phosphatidylethanolamine, and phosphatidylserine were added $(50,000 \mathrm{cpm}$ of each) to assess recovery. Extracts were stored at $-20^{\circ} \mathrm{C}$ in one phase. Then $1 \mathrm{ml}$ $\mathrm{CHCl}_{3}$ and $500 \mu \mathrm{l}$ of $0.1 \mathrm{M} \mathrm{Na}_{2} \mathrm{EDTA}, 2 \mathrm{M} \mathrm{KCl}$ were added to separate the layers. The lower $\mathrm{CHCl}_{3}$ layer was removed and the upper layer was extracted three times with $1 \mathrm{ml}$ (each time) $\mathrm{CHCl}_{3}$. The $\mathrm{CHCl}_{3}$ layers were combined, evaporated to dryness, and resuspended in $\mathbf{0 . 5}$ $\mathrm{ml}$ of $\mathrm{CHCl}_{3}$. Neutral and phospholipids were isolated by thin-layer chromatography as described below.

Determination of labeled diacylglycerol production. Glomeruli were prepared from 20 kidneys (10-20 mg protein), resuspended in 13 $\mathrm{ml}$ of KRBG, $95 \% \mathrm{O}_{2}, 5 \% \mathrm{CO}_{2}$, and incubated for $1 \mathrm{~h}$ with $50 \mu \mathrm{Ci}$ of [ ${ }^{3} \mathrm{H}$ ]myristate in $25 \mathrm{ml}$ flasks $(2 \mathrm{ml} /$ flask). The additions shown were present for the final $15 \mathrm{~min}$ of incubation. After $60 \mathrm{~min}$, glomeruli were centrifuged, and lipids extracted as described above. An aliquot of the lipid extract was mixed with $100 \mu \mathrm{g}$ of carrier diacylglycerol. The sample was applied to a silica gel thin layer plate and the plate developed in hexane/ethyl ether/acetic acid 80:20:2 (19). Spots were visualized with $I_{2}$ vapor, scraped and counted.

Determination of $\left[{ }^{32} \mathrm{P}\right]$ orthophosphate incorporation into phospholipids. Glomeruli were prepared from 20 kidneys, suspended in $8 \mathrm{ml}$ of $\mathrm{KRBG}, 95 \% \mathrm{O}_{2}, 5 \% \mathrm{CO}_{2}$ and incubated for $4 \mathrm{~h}$ at $37^{\circ} \mathrm{C}$ in duplicate with or without $5 \mathrm{mM}$ inositol ( $2 \mathrm{ml} / 25 \mathrm{ml}$ flask). [ $\left.{ }^{32} \mathrm{P}\right]$ Orthophosphate $(10 \mu \mathrm{Ci})$ was present in each incubate. At the end of $4 \mathrm{~h}$ the glomeruli were washed three times by centrifugation in $20 \mathrm{ml}$ of KRBG, resuspended in $1 \mathrm{ml}$ of $\mathrm{H}_{2} \mathrm{O}$ and lipid extracts prepared as described above. Unlabeled phosphatidylinositol-4-phosphate (PIP) and phosphatidylinositol-4,5-bisphosphate ( PIP $\left._{2}\right)(100 \mu \mathrm{g}$ each) were added to the lipid extracts as carriers. The samples were then chromatographed on oxalate impregnated silica gel $G$ thin layer plates and developed in $\mathrm{CHCl}_{3} / \mathrm{CH}_{3} \mathrm{OH} / 4 \mathrm{~N} \mathrm{NH}_{4} \mathrm{OH}$ (45:35:10) (20). The lipids were visualized by exposure to $I_{2}$ vapor, scraped, and counted. Results shown were corrected for recoveries based on that of added $\left[{ }^{14} \mathrm{C}\right]$ phospholipids, which were routinely $40-50 \%$.

Determination of labeled inositol phosphates. Glomeruli were prepared from 20 kidneys, suspended in $\mathrm{KRBG}$ equilibrated with $95 \% \mathrm{O}_{2}$, $5 \% \mathrm{CO}_{2}$, and incubated for $2 \mathrm{~h}$ with $75 \mu \mathrm{Ci}\left[{ }^{3} \mathrm{H}\right]$-myo-inositol. The

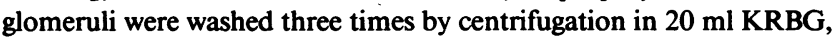
resuspended in $20 \mathrm{ml} \mathrm{KRBG}$ plus $10 \mathrm{mM} \mathrm{LiCl}$, aliquoted $(2 \mathrm{ml} / 25-\mathrm{ml}$ flask) and incubated in triplicate at $37^{\circ} \mathrm{C}$ for $10 \mathrm{~min}$ in a shaking incubator. Additions were present for the final $3 \mathrm{~min}$ of incubation. Incubations were conducted in triplicate and extracts combined for isolation of inositol phosphates. The incubation was stopped by homogenization in $0.67 \mathrm{ml}$ of $10 \% \mathrm{HClO}_{4}$ on ice. After centrifugation, inositol-1-phosphate (IP), inositol-1,4-bisphosphate (IP 2$)$, and inositol-1,4,5-trisphosphate $\left(\mathrm{IP}_{3}\right)$ were separated by Dowex formate chromatography as previously described (21). $\left[{ }^{3} \mathrm{H}\right] \mathrm{IP},\left[{ }^{3} \mathrm{H}\right] \mathrm{IP}{ }_{2}$, and $\left[{ }^{3} \mathrm{H}\right] \mathrm{IP}_{3}$ were used as standards.

Preparation, partial purification, and assay of protein kinase $C$. Glomeruli were prepared from 10 kidneys for each experimental condition examined and incubated as described in the footnotes to the Tables. Subcellular fractions were prepared, fractionated on DEAE cellulose, and assayed as previously described by Kraft et al. $(22,23)$. Glomeruli were homogenized in $5 \mathrm{ml}$ of $20 \mathrm{mM}$ Tris, pH 7.5, $0.5 \mathrm{mM}$ EDTA, $2 \mathrm{mM}$ phenyl methyl-sulfonylfluoride, $0.5 \mathrm{mM}$ benzamidine (buffer A) and centrifuged for $60 \mathrm{~min}$ at $100,000 \mathrm{~g}$. The supernatant (1.5-2.5 mg protein) was applied to a DEAE cellulose column. The $100,000 \mathrm{~g}$ pellet was resuspended in $5 \mathrm{ml}$ of buffer A plus $0.2 \%$ Triton $\mathrm{X}-100$ and incubated for $1 \mathrm{~h}$ at $0^{\circ} \mathrm{C}$ with stirring. The solubilized particulate fraction was then centrifuged at $100,000 \mathrm{~g}$ and the supernatant (4-5 mg/protein) applied to a DEAE cellulose column $(4 \times 0.75$ $\mathrm{cm}$ ). The columns were washed with $10 \mathrm{ml}$ each of buffer A. Activity was eluted with $40 \mathrm{ml}$ of a linear gradient of $0.1 \mathrm{M} \mathrm{NaCl}$ in buffer $\mathrm{A}$. Protein kinase $\mathrm{C}$ activity routinely eluted as a sharp peak between 0.03 and $0.04 \mathrm{M} \mathrm{NaCl}$. As previously reported for other systems $(22,23)$, protein kinase $\mathrm{C}$ activity in subcellular fractions of crude homeogenates of glomeruli was only $20 \%$ of that found following DEAE cellulose chromatography of the fractions. Accordingly, all preparations were routinely purified by DEAE cellulose before assay.

Reaction mixtures for the determination of protein kinase $\mathrm{C}$ activity contained $20 \mathrm{mM}$ Tris, $10 \mathrm{mM} \mathrm{MgCl}, 400 \mu \mathrm{g} / \mathrm{ml}$ histone (Type III-S), $50 \mu \mathrm{M}\left[{ }^{32} \mathrm{P}\right] \mathrm{ATP}(1 \mu \mathrm{Ci}), 1 \mathrm{mM} \mathrm{CaCl}_{2}$ and where indicated 80 $\mu \mathrm{g} / \mathrm{ml}$ phosphatidylserine plus $2 \mu \mathrm{M}$ 1-oleoyl 2-acetyl glycerol (OAG) in a final volume of $75 \mu$ l. These concentrations of $\mathrm{CaCl}_{2}$, phosphatidylserine, and OAG yielded optimal expression of enzyme activity. DEAE cellulose column fractions were assayed with $1 \mathrm{mM} \mathrm{CaCl}$ and in the presence and absence of phosphatidylserine plus OAG. Protein kinase $\mathrm{C}$ activity is defined as the difference between activity measured with $\mathrm{Ca}^{2+}$ in the presence versus the absence of OAG plus phosphatidylserine. Aliquots of phosphotidylserine $(10 \mathrm{mg} / \mathrm{ml}$ ethanol) and OAG $\left(0.25 \mathrm{mg} / \mathrm{ml}\right.$ ethanol) were evaporated under $\mathrm{N}_{2}$ and sonicated on ice in $20 \mathrm{mM}$ Tris, $\mathrm{pH} 7.6$ before addition to the enzyme assay mixture. Incubations were for $5 \mathrm{~min}$ at $30^{\circ} \mathrm{C}$. Reactions were stopped by pipetting $50 \mu \mathrm{l}$ of the assay mixtures onto a square $(1 \times 1 \mathrm{~cm})$ of chromatography paper (31 ET; Whatman Inc., Clifton, NJ), which had been dipped in $10 \%$ TCA, $2 \mathrm{mM} \mathrm{NaH} \mathrm{mO}_{4}$. Filter papers were then washed with agitation in $250 \mathrm{ml}$ of ice-cold $10 \%$ TCA for $15 \mathrm{~min}$ followed by four changes of $10 \%$ TCA at room temperature. The papers were soaked in $95 \%$ ethanol for $5 \mathrm{~min}$ and allowed to air dry before counting. Enzyme activity was linear for 2-5 min under all conditions of assay employed.

Determination of inositol. Glomeruli from eight kidneys were pooled for each determination of inositol content and homogenized in $3 \mathrm{ml}$ of water. [ ${ }^{3} \mathrm{H}$ ] Inositol $(0.375 \mu \mathrm{Ci})$ was added to each extract to monitor recovery and the extent of derivatization. The homogenates were centrifuged at $100,000 \mathrm{~g}$ for $1.5 \mathrm{~h}$ and the supernatant incubated for $40 \mathrm{~min}$ at $37^{\circ} \mathrm{C}$ with $24 \mathrm{U}$ of glucose oxidase. Supernatants were deproteinized with the Centrifree Micropartition System (Amicon Corp., Danvers, MA) and fractionated on a Sugar Pak column (6.5 $\mathrm{mm} \times 30 \mathrm{~cm}$; Waters Associates, Milford, MA). The inositol fraction was then derivatized with $p$-chloronitrobenzene and further fractionated on a Waters microporasil column $(6.5 \mathrm{~mm} \times 30 \mathrm{~cm})$ as previously described (24). The $p$-chloronitrobenzoate derivative of inositol was quantitated by absorption at $254 \mu \mathrm{m}$.

Statistics. When more than one mean value was to be compared to a single control value, the significance of differences was first determined by analysis of variance (ANOVA). If significant differences were obtained by ANOVA the significance of differences between any two average values was then determined by Student's independent test. Experiments were conducted three or four times as indicated in the footnotes to the Tables and legends to the Figures (degrees of freedom $=4$ or 6 ).

Materials. Sorbinil was the generous gift of Pfizer Inc., Groton, CT. The sources of all other reagents have been previously reported $(25,26)$.

\section{Results}

Fig. 1 illustrates the content of inositol in glomeruli isolated from control and diabetic rats. As shown, inositol content was reduced by $58 \%$ in glomeruli from diabetic rats compared to controls. Treatment of diabetic rats with insulin to achieve near euglycemia prevented the fall in glomerular inositol content. Moreover, as is also shown in Table I, treatment of diabetic rats with the aldose reductase inhibitor, sorbinil also prevented the fall in glomerular inositol content. The average weight of the rats in each group was not significantly different at the start of the study $(244 \pm 5 \mathrm{~g})$. The diabetic rats that were 


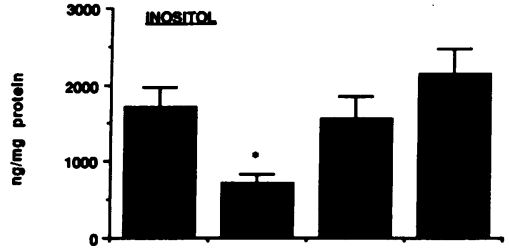

Figure 1. Glomerular inositol content and plasma glucose concentrations in control and diabetic rats. Glomeruli were isolated from eight kidneys and extracted as described in Methods for determination of free inositol. Insulin treated diabetic rats received $10 \mathrm{U}$ of regular Iletin II pork insulin $/ \mathrm{kg}$ per $\mathrm{d}$ by osmotic minipump. Sorbinil treated diabetic rats received 20 $\mathrm{mg} / \mathrm{kg}$ per $\mathrm{d}$ in the diet. All rats were studied between 1 and $2 \mathrm{wk}$ after injection of streptozotocin or its diluent (controls). Results shown are means \pm SE of duplicate determinations on four separate glomerular extracts $(n=4) .{ }^{*} P<0.05$ compared to corresponding value in control rats.

not treated with insulin lost $\sim 8 \%$ of their body weight. Insulin-treated diabetic rats gained weight at the same rate as control rats. Sorbinil feedings had no effect on body weight. Animal weights at sacrifice were: control $261 \pm 14$; diabetic $223 \pm 10$; insulin-treated diabetic $264 \pm 16$; sorbinil-treated diabetic $221 \pm 18 \mathrm{~g} \pm \mathrm{SE}$. Plasma glucose at the time of death was markedly elevated in the untreated and sorbinil treated diabetic rats, but near control values in the insulin treated diabetic rats (Fig. 1). Sorbinil treatment had no effect on body weight or plasma glucose in control rats, as previously reported (27).

Table I illustrates ${ }^{32} \mathrm{P}$ incorporation into phospholipids of glomeruli from diabetic versus control rats. In these studies isolated glomeruli were incubated for $4 \mathrm{~h}$ with $\left[{ }^{32} \mathrm{P}\right]-$ orthophosphate. The results reflect the turnover of the individual labeled phospholipids. As shown, turnover of labeled PIP and $\mathrm{PIP}_{2}$ were markedly reduced in glomeruli from diabetic versus control rats. By contrast, the turnover of labeled phosphatidylinositol, phosphatidylethanolamine, and phosphatidylcholine plus phosphatidylserine was not significantly different between the two groups. As also shown in Table I, addi- tion of inositol to the incubation mixture significantly enhanced the turnover of labeled polyphosphoinositides of both control and diabetic glomeruli and abolished the differences between the two groups. These observations suggest that the reduction in turnover of labeled PIP and PIP $_{2}$ seen in glomeruli from diabetic rats was a consequence of the reduced inositol content of the diabetic glomeruli.

Table II illustrates the subcellular distribution of protein kinase $\mathrm{C}$ in homogenates of glomeruli from normal and diabetic rats. As shown, $88 \%$ of enzyme activity was recovered in the $100,000 \mathrm{~g}$ soluble fraction of glomeruli isolated from control rats. By contrast, only $55 \%$ of the protein kinase $\mathrm{C}$ activity was found in the soluble fraction of glomeruli isolated from diabetic rats. Total protein kinase $C$ activity, calculated as the sum of activity recovered following DEAE cellulose chromatography of the soluble plus solubilized particulate fractions of glomerular homogenates, was not significantly different between diabetic and control rats. The specific activity of particulate protein kinase $\mathrm{C}$ was fourfold higher in glomeruli from diabetic compared to control rats, whereas the specific activity of protein kinase $\mathrm{C}$ in the soluble fraction was significantly lower in glomeruli from diabetic rats compared to control. These observations imply that the higher protein kinase $\mathrm{C}$ activity in particulate fractions from glomerular homogenates from diabetic rats was due to translocation of enzyme activity from the soluble to the particulate fraction, an index of enzyme activation. As is also shown in Table II, treatment of diabetic rats with insulin prevented the translocation of glomerular protein kinase $C$ to the particulate fraction. By contrast, sorbinil treatment had no effect on the subcellular distribution of protein kinase $\mathrm{C}$ in diabetic rats.

The results presented in Tables I-II and Fig. 1 suggest that despite a reduction in glomerular inositol content and polyphosphoinositide turnover, protein kinase $C$ is activated in glomeruli from diabetic rats compared to controls. To examine the potential mechanisms by which the diabetic state may mediate protein kinase $\mathrm{C}$ activation in glomeruli, we assessed the effects of glucose on the subcellular distribution of protein kinase $\mathrm{C}$ in glomeruli from control rats. In these studies the concentration of glucose in the incubation media was varied from 100 to $1000 \mathrm{mg} / \mathrm{dl}$. As shown in Fig. 2, an increase in glucose concentration from 100 to $200 \mathrm{mg} / \mathrm{dl}$ resulted in a significant increase in the percent of protein kinase $C$ activity in the particulate fraction and a concurrent decline in soluble

Table I. Effects of Inositol on $\left[{ }^{32} P\right]$ Orthophosphate Incorporation into Phospholipids of Glomeruli Isolated from Control and Diabetic Rats

\begin{tabular}{|c|c|c|c|c|c|}
\hline & Phosphatidylinositol & $\begin{array}{l}\text { Phosphatidylinositol- } \\
\text { 4-Phosphate }\end{array}$ & $\begin{array}{l}\text { Phosphatidylinositol-4,5- } \\
\text { bisphosphate }\end{array}$ & $\begin{array}{l}\text { Phosphatidylcholine- } \\
\text { + Phosphatidylserine }\end{array}$ & Phosphatidylethanolamine \\
\hline \multicolumn{6}{|c|}{$\mathrm{cpm} / \mathrm{mg}$ protein } \\
\hline Control & $3,817 \pm 1,780$ & $496 \pm 74$ & $882 \pm 138$ & $5,174 \pm 1,516$ & $2,352 \pm 714$ \\
\hline +Inositol & $4,173 \pm 1,256$ & $512 \pm 98$ & $956 \pm 172$ & $7,285 \pm 2,052$ & $2,856 \pm 302$ \\
\hline Diabetic & $3,308 \pm 1,316$ & $255 \pm 97^{*}$ & $204 \pm 98^{*}$ & $6,854 \pm 2,505$ & $2,284 \pm 752$ \\
\hline +Inositol & $4,892 \pm 1,956$ & $482 \pm 105^{\ddagger}$ & $751 \pm 141^{\ddagger}$ & $6,154 \pm 1,924$ & $3,105 \pm 809$ \\
\hline
\end{tabular}

Glomeruli were prepared from 20 kidneys and incubated for $4 \mathrm{~h}$ in duplicate in the presence and absence of $5 \mathrm{mM}$ inositol. $\left.{ }^{32} \mathrm{P}\right] \mathrm{Orthophos}-$ phate $(10 \mu \mathrm{Ci})$ was present in each incubation. At the end of $4 \mathrm{~h}$ phospholipids were extracted and isolated by thin-layer chromatography as described in Methods. Results shown are means \pm SE of determination on duplicate extracts from three separate experiments. ${ }^{*} P<0.05$ compared to corresponding value in glomeruli from control rats. ${ }^{\ddagger} P<0.05$ compared to corresponding value in the absence of inositol. 


\begin{tabular}{llccc}
\hline & \multicolumn{2}{c}{ Specific activity } & & \\
\cline { 2 - 4 } & \multicolumn{1}{c}{ Soluble } & Particulate & Total activity & p Soluble \\
\hline & \multicolumn{2}{c}{ pmol/min/mg protein } & pmol/min/ \\
& & & & \\
Cong hogenate protein & \\
Diabetic & $1,651 \pm 114$ & $93 \pm 10$ & $574 \pm 41$ & $88 \pm 7$ \\
Insulin-treated diabetic & $1,262 \pm 99^{*}$ & $482 \pm 124^{*}$ & $523 \pm 46$ & $55 \pm 3^{*}$ \\
Sorbinil-treated diabetic & $1,708 \pm 97$ & $146 \pm 22^{\ddagger}$ & $551 \pm 89$ & $84 \pm 8^{\ddagger}$ \\
& $1,198 \pm 163^{*}$ & $459 \pm 94^{*}$ & $491 \pm 63$ & $51 \pm 4^{*}$
\end{tabular}

Glomeruli were homogenized and a 100,000 $\mathrm{g}$ soluble and solubilized particulate fraction prepared as described in Methods. The soluble and solubilized particulate fractions were partially purified by DEAE cellulose chromatography before assay. Units of specific activity are pmol/min per $\mathrm{mg}$ of protein in the soluble or solubilized particulate fraction. Units for total activity are pmol/min per mg protein in the soluble plus solubilized particulate fraction. The percentage of activity in the soluble fraction was calculated from the total activity in the soluble plus particulate fraction that was recovered from DEAE cellulose. Where indicated rats were treated with insulin or sorbinil as described in the footnote to Table I. Results shown are mean $\pm \mathrm{SE}$ of determinations on four separate glomerular homogenates. ${ }^{*} P<0.05$ compared to corresponding value in glomeruli from control rats. ${ }^{\ddagger} P<0.05$ compared to corresponding value in glomeruli from untreated diabetic rats.

activity. Increasing media glucose from 200 to $600 \mathrm{mg} / 100 \mathrm{ml}$ further increased the percentage of protein kinase $\mathrm{C}$ in the particulate fraction with a concomitant decline in soluble activity. Increasing the glucose concentration to $1,000 \mathrm{mg} / \mathrm{dl}$ yielded results which were not different from those obtained at $600 \mathrm{mg} / \mathrm{dl}$ glucose. As is also shown in Fig. 2, addition of 1,000 $\mathrm{mg} / \mathrm{dl}$ of the nonmetabolizable glucose analogue, 2-deoxyglucose to glomeruli incubated in KRBG, which contained 100 $\mathrm{mg} / \mathrm{dl}$ glucose, had no effect on the subcellular distribution of protein kinase $\mathrm{C}$ in rats when compared to that observed in glomeruli incubated with $100 \mathrm{mg} / \mathrm{dl}$ glucose alone. 2-deoxyglucose had no effect on viability of glomeruli as assessed by trypan blue exclusion. Similarly, addition of mannitol $(1,000$ $\mathrm{mg} / \mathrm{dl}$ ) had no effect on the subcellular distribution of protein kinase $\mathrm{C}$ in glomerular homogenates (control 84 3 ; mannitol

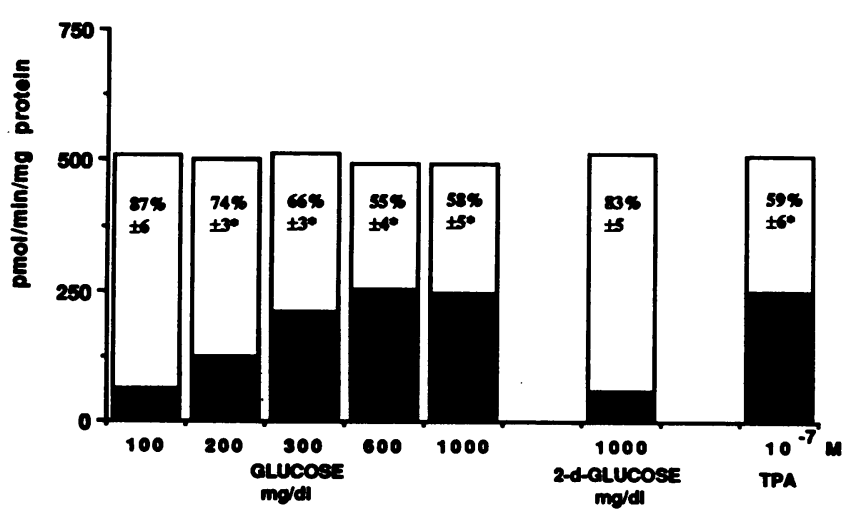

Figure 2. Effects of glucose on the subcellular distribution of protein kinase $\mathrm{C}$ in glomerular homogenates. Studies were conducted as described in the footnote to Table II. Where shown glucose, 2-deoxyglucose or TPA was added to give the final indicated concentration in the initial 10-min glomerular incubation. Enzyme activities were measured in the $100,000 \mathrm{~g}$ soluble ( $(\square)$ and solubilized particulate ( $(\bullet)$ fractions following partial purification on DEAE cellulose and expressed on the basis of milligrams of protein in the soluble plus solubilized particulate fraction. Two experimental parameters were studied with a single preparation of glomeruli from 10 kidneys and each experiment was repeated three times. ${ }^{*} P<0.05$ compared to corresponding value obtained with $100 \mathrm{mg} / \mathrm{dl}$ glucose.
$81 \pm 5 \%$ soluble activity \pm SE of three separate experiments). As is also shown in Fig. 2, incubation of glomeruli with 12-O-tetradecanoyl phorbol-13-acetate (TPA) a known activator of protein kinase $\mathrm{C}(22,23)$, induced translocation of protein kinase $\mathrm{C}$ from the soluble to the particulate cell fraction.

The time course of glucose action on the subcellular distribution of protein kinase $\mathrm{C}$ is illustrated in Fig. 3. Glomeruli were incubated for a total of $30 \mathrm{~min}$ in KRBG. The concentration of glucose in the media was raised to $300 \mathrm{mg} / \mathrm{dl}$ for the final incubation times indicated in the figure. As shown in Fig. 3 , percent soluble protein kinase $\mathrm{C}$ was significantly decreased by $2 \mathrm{~min}$ with maximal decline observed by $10 \mathrm{~min}$ after raising the glucose concentration to $300 \mathrm{mg} / \mathrm{dl}$. The percent soluble protein kinase $\mathrm{C}$ remained significantly reduced 20 min after raising glucose to $300 \mathrm{mg} / \mathrm{dl}$ but by $30 \mathrm{~min}$ returned to values not different from those in glomeruli incubated at $100 \mathrm{mg} / \mathrm{dl}$ glucose. An analogous time course was observed when media glucose was increased from 100 to $1,000 \mathrm{mg} / \mathrm{dl}$ (not shown).

Fig. 4 illustrates the effects of glucose and 2-deoxyglucose on the turnover of labeled diacylglycerol in glomeruli from control rats. In these studies glomeruli were initially incubated for 50 min with $\left[{ }^{3} \mathrm{H}\right]$ myristic acid in $\mathrm{KRBG}$ which contained $100 \mathrm{mg} / \mathrm{dl}$ of glucose. Glucose or 2-deoxyglucose was then added to give the final concentration indicated in Fig. 4 and the incubation continued for $10 \mathrm{~min}$. As shown, in Fig. 4, raising the concentration of glucose from 100 to $600 \mathrm{mg} / \mathrm{dl}$ progressively increased the formation of labeled diacylglycerol approximately twofold. The lowest concentration of glucose which gave a detectable increase in labeled diacylglycerol was $200 \mathrm{mg} / \mathrm{dl}$. Raising the glucose concentration from 600 to $1,000 \mathrm{mg} / \mathrm{dl}$ had no further effect on labeled diacylglycerol turnover. As is also shown in Fig. 4, addition of $1,000 \mathrm{mg} / \mathrm{dl}$ 2-deoxyglucose to glomeruli incubated in KRBG with 100 $\mathrm{mg} / \mathrm{dl}$ glucose had no effect on labeled diacylglycerol formation compared to that seen in glomeruli incubated in 100 $\mathrm{mg} / \mathrm{dl}$ glucose. In contrast to the results obtained with $\left[{ }^{3} \mathrm{H}\right]-$ myristate, glucose did not stimulate labeled diacylglycerol production when glomeruli were incubated with $\left[{ }^{3} \mathrm{H}\right]-$ arachidonate. While the reasons for this are not clear, differences in the pattern of lipid labeling with these two fatty acids 


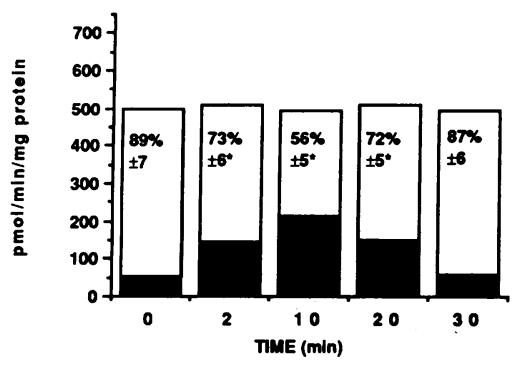

Figure 3. Time course of glucose actions on protein kinase $\mathrm{C}$ in glomerular homogenates. Studies were conducted as described in the footnote to Table II, glomeruli were incubated for a total of $30 \mathrm{~min}$ in KRBG. Where indicated the media glucose concentration was raised from 100 to $300 \mathrm{mg} / \mathrm{dl}$ for the final time of incubation shown. Enzyme activities were measured in the $100,000 \mathrm{~g}$ soluble ( $\square$ ) and solubilized particulate ( $\square$ ) fractions following partial purification on DEAE cellulose and expressed on the basis of milligrams protein in the soluble plus solubilized particulate fraction. Two experimental parameters were studied with a single preparation of glomeruli from 10 kidneys and each experiment was repeated three times. ${ }^{*} P<0.05$ compared to corresponding value obtained when glomeruli were incubated with $100 \mathrm{mg} / \mathrm{dl}$ glucose (zero time).

may be the basis for the divergent responses to glucose. Thus, although the total amount of label incorporated into lipids was similar for the two fatty acids, $70 \%$ of the label from $\left[{ }^{3} \mathrm{H}\right]-$ myristate was incorporated into di- and triglycerides whereas the remainder was in phospholipids. In the case of $\left[{ }^{3} \mathrm{H}\right]-$ arachidonate the reverse was true. The higher level of incorporation of $\left[{ }^{3} \mathrm{H}\right]$ myristate into neutral lipids may enhance the ability to detect alterations in labeled diacylglycerol production. Secondly, $\left[{ }^{3} \mathrm{H}\right]$ myristate was preferentially incorporated into phosphatidylcholine $(90 \%)$ relative to other phospholipids, whereas this was not true for $\left[{ }^{3} \mathrm{H}\right]$ arachidonate $(49 \%$ into phosphatidylcholine). Finally, previous studies in other tissues have demonstrated the presence of myristic acid but not arachidonic acid in the phosphatidylinositol-glycan moiety (28). This lipid may also be a source of glucose stimulated labeled diacylglycerol production in glomeruli. The use of labeled myristate might thus permit detection of diacylglycerol generated from phosphatidylinositol-glycan in addition to that derived from de novo synthesis of phospholipids or phospholipase $\mathrm{C}$ induced breakdown of phosphatidylcholine.

The ability of glucose to increase labeled diacylglycerol production could be due to an action of glucose to enhance inositol phospholipid breakdown. This possibility was assessed directly. Table III compares the effects of glucose and angiotensin II on labeled inositol phosphate production in glomeruli

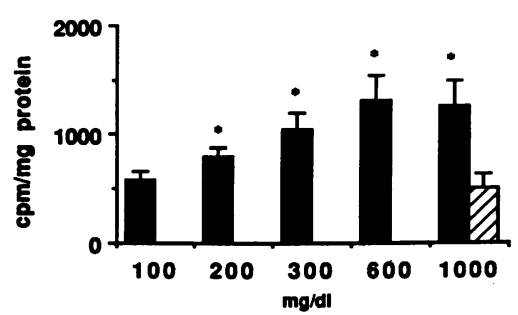

Figure 4. Effects of glucose on $\left[{ }^{3} \mathrm{H}\right]-$ diacylglycerol turnover by glomeruli from control rats. Glomeruli were incubated in $\mathrm{KRBG}$ at $37^{\circ} \mathrm{C}$ for 60 min with $15 \mu \mathrm{Ci}$ of $\left[{ }^{3} \mathrm{H}\right]$ myristate as described in Methods. Where in-

dicated, glucose or 2-deoxyglucose was added to give the indicated concentration during the final $10 \mathrm{~min}$ of the incubation. All six experimental parameters were studied with the same glomerular preparation, representing 20 kidneys and each experiment was repeated three times. ${ }^{*} P<0.05$ compared to corresponding values obtained with $100 \mathrm{mg} / \mathrm{dl}$ glucose.
Table III. Effects of Glucose and Angiotensin II on Inositol Phosphate Production in Glomeruli from Control and Diabetic Rats

\begin{tabular}{llrc}
\hline & \multicolumn{1}{c}{ IP } & \multicolumn{1}{c}{$\mathrm{IP}_{2}$} & \multicolumn{1}{c}{$\mathrm{IP}_{3}$} \\
\hline & \multicolumn{3}{c}{ cpm/mg protein } \\
Control & $3,322 \pm 498$ & $806 \pm 134$ & $279 \pm 32$ \\
$+900 \mathrm{mg} /$ dl glucose & $2,953 \pm 354$ & $765 \pm 117$ & $312 \pm 39$ \\
$+10^{-7} \mathrm{M}$ angiotensin II & $6,413 \pm 1,154^{*}$ & $1,423 \pm 173^{*}$ & $406 \pm 52^{*}$
\end{tabular}

Glomeruli were prepared from 20 kidneys and prelabeled with 75 $\mu \mathrm{Ci}$ of $\left[{ }^{3} \mathrm{H}\right]-m y o-i n o s i t o l$. They were then washed and incubated in triplicate in KRBG which contained $100 \mathrm{mg} / \mathrm{dl}$ glucose for $10 \mathrm{~min}$ at $37^{\circ} \mathrm{C}$. The additions shown were present for the final $3 \mathrm{~min}$ of incubation. IP, IP $\mathrm{I}_{2}$, and $\mathrm{IP}_{3}$ were extracted, isolated by Dowex chromatography and counted as described in Methods. Results shown are mean $\pm \mathrm{SE}$ of determinations from three separate experiments. ${ }^{*} P<0.05$ compared to corresponding value with no addition.

from control rats. Raising the glucose concentration of the media from 100 to 300 (not shown) or $1,000 \mathrm{mg} / \mathrm{dl}$ (Table III) had no effect on production of IP, $\mathrm{IP}_{2}$, or $\mathrm{IP}_{3}$. By contrast, angiotensin II stimulated labeled inositol phosphate production 1.5-2-fold.

\section{Discussion}

Previous studies in rat diabetic nerve have implicated enhanced polyol pathway activity, and reduced tissue myo-inositol content in the mediation of reduced nerve conduction velocity in the diabetic rat $(2,10,11,29)$. Phosphatidylinositol content of diabetic nerve is reduced and several observations have implicated the reduction in phosphatidylinositol in the mediation of reduced $\left(\mathrm{Na}^{+}, \mathrm{K}^{+}\right)$-ATPase activity and impaired nerve conduction velocity (4). It recently has been suggested that a lower phosphatidylinositol content of nerve might lead to reduced diacylglycerol production and a reduction in the state of activation of protein kinase $C(2)$. The observation that TPA, a protein kinase $C$ activator, enhances nerve conduction velocity in diabetic rats further suggests that a defect in protein kinase $C$ activation may contribute to this neural defect (12). Recently, total protein kinase $C$ has been reported to be reduced in diabetic nerve (30). However, this observation is difficult to interpret since the reduction in total protein kinase $\mathrm{C}$ activity was due to a loss in soluble activity alone. The percentage of enzyme activity associated with the particulate fraction, an index of enzyme activation (30), was in fact higher in diabetic compared to normal nerve. Moreover, the turnover of polyphosphoinositides (3) and the phosphorylation of specific nerve proteins which are thought to be substrates for protein kinase $C$ in vitro (14), have both been reported to be increased, rather than decreased in diabetic nerve despite the reduction in inositol and phosphatidylinositol content. Accordingly, in diabetic nerve there does not appear to be a simple relationship between reduced myo-inositol content and the activity of the inositol phospholipid/protein kinase $\mathrm{C}$ signalling pathway.

The results of this study clearly demonstrate that the free inositol content of glomeruli isolated from streptozotocin diabetic rats is reduced by $1-2 \mathrm{wk}$ after induction of diabetes. This is consistent with previous studies in diabetic nerve (2) and 
lens (2) and in isolated glomeruli obtained 7-10 wk after induction of diabetes (5). The reduction in glomerular inositol content is likely related to hyperglycemia or some other consequence of the diabetic state, rather than to an action of streptozotocin, since treatment of the diabetic rats with insulin to maintain near euglycemia prevented the fall in glomerular inositol content. Indeed, glucose has been reported to inhibit the cellular uptake of inositol (31). In the present study and consistent with previous observations (2), sorbinil was found to prevent the fall in glomerular inositol content seen in the diabetic rat. This suggests that increased polyol pathway activity may contribute to the decrease in inositol content. However, the mechanism by which sorbinil prevents the fall in inositol is not known (2). Sorbinil has been shown to bind to glomeruli (32) and thus might influence membrane transport through mechanisms that do not involve aldose reductase activity. In this regard, we have been unable to demonstrate an increase in glomerular sorbitol content at 1-2 wk after induction of diabetes, at a time when inositol content was reduced (unpublished observations). Thus, sorbinil may prevent glomerular inositol depletion in diabetes through a mechanism other than inhibition of aldose reductase, although this remains uncertain.

This study also demonstrates that the turnover of the labeled polyphosphoinositides PIP and PIP $_{2}$ is reduced in glomeruli from diabetic rats. Reduced turnover of labeled PIP and $\mathrm{PIP}_{2}$ appeared to be a consequence of reduced glomerular free inositol content, since the addition of inositol to the incu-

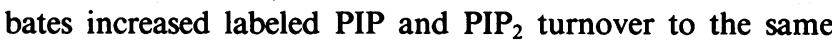
absolute value in glomeruli from diabetic and control rats. The reduced turnover of labeled PIP and PIP $_{2}$ was selective relative to turnover of the other major phospholipids, which did not differ in glomeruli from diabetic and control rats. The finding that phosphatidylinositol turnover was not reduced in glomeruli from diabetic rats despite the reduction in PIP and PIP $_{2}$ turnover may reflect the fact that PIP and PIP $_{2}$ are cycling more rapidly than PI, that differences in the turnover of a small pool of PI occurred, but were masked by the slower turnover of a larger pool of phosphatidylinositol, or that both of these phenomena were operative.

Despite the reduced inositol content and the reduced turnover of labeled PIP and PIP ${ }_{2}$, protein kinase $\mathrm{C}$ appeared to be activated in glomeruli from diabetic rats as reflected by an increase in the percentage of enzyme activity which is associated with the particulate fraction. The increase in particulate protein kinase $\mathrm{C}$ observed in glomeruli from diabetics was not due to an alteration in protein content of the subcellular fractions, since the specific activity of protein kinase $\mathrm{C}$ in the particulate fraction of glomeruli from diabetic rats was also increased. Moreover, total enzyme activity of the soluble plus particulate fraction did not differ between glomeruli from diabetics and controls when expressed on the basis of protein. Thus, the increase in particulate protein kinase $C$ appeared to be due to translocation of the enzyme from the soluble to the particulate fraction. Nevertheless, alternate interpretations of these findings must be considered. Several isozymic forms of protein kinase $\mathrm{C}$ have been described that differ in their tissue distribution and subcellular localization (33). Each isozyme is known to be encoded by a different gene and thus may be differentially expressed (33). We can not exclude the possibility that the shift in subcellular distribution of protein kinase $\mathrm{C}$ that we observed in glomeruli from diabetic rats reflects an altered pattern of protein kinase $\mathrm{C}$ isozyme expression. Furthermore, protein kinase $\mathrm{C}$ has been implicated in several cellular processes and some lines of evidence suggest that different isozymes may be responsible for diverse cellular responses (34-36). Thus, the functional significance of increased particulate protein kinase $\mathrm{C}$ in glomeruli from diabetic rats remains to be examined.

Chronic exposure to high concentrations of phorbol esters in vitro has previously been shown to cause loss of protein kinase $C$ activity (37). If protein kinase $C$ were chronically activated in glomeruli from diabetic rats, we might have expected to see loss of total enzyme activity. This was not observed. In this regard, it is not known whether downregulation of protein kinase $\mathrm{C}$ occurs in vivo with physiologic activators that increase diacylglycerol. Previous reports of increased particulate protein kinase $C$ in mice fed a high fat diet for 4-6 wk (38), in fibroblasts from psoriatic patients (39) and in the luminal membranes of proximal tubules from 1 mo streptozotocin diabetic rats (40) suggest that downregulation may not occur with chronic stimulation in vivo. Recently, Wolfman and Macara (41) demonstrated that ras transformed fibroblasts ( $2 \mathrm{wk}$ ) possess elevated diacylglycerol and a 4-20-fold increase in $80 \mathrm{k}$ protein phorphorylation, a measure of endogenous protein kinase $\mathrm{C}$ activity. Total protein kinase $\mathrm{C}$ was reduced by only $25 \%$ in the transformed cells (41), suggesting that protein kinase $\mathrm{C}$ appeared to be both activated and modestly downregulated in these cells. Thus chronic exposure to elevated diacylglycerol, as opposed to TPA, may have minor if any effects on total protein kinase $\mathrm{C}$ activity.

Translocation of protein kinase $\mathrm{C}$ to the particulate fraction is often observed following exposure of cells to TPA or diacylglycerol analogues, known activators of this enzyme system $(22,23)$. In the present study, exposure of glomeruli from normal rats to TPA similarly resulted in apparent translocation of protein kinase $\mathrm{C}$ to the particulate fraction. Glucose had an effect on protein kinase $C$ analogous to TPA, implying that glucose also induced enzyme activation. The ability of glucose to activate protein kinase $C$ in normal glomeruli supports a role for hyperglycemia per se in the activation of protein kinase $\mathrm{C}$ observed in glomeruli isolated from diabetic rats. The observation that 2-deoxyglucose did not mimic the effects of glucose to activate protein kinase $C$ in glomeruli suggests that a metabolic effect of glucose mediates activation of protein kinase C. Moreover, the results with 2-deoxyglucose and mannitol exclude an osmotic action of glucose in the activation of glomerular protein kinase C. Conversely, studies in diabetic rats treated with sorbinil or insulin indicate that activation of glomerular protein kinase $\mathrm{C}$ is dissociated from changes in glomerular inositol content. Thus, sorbinil treatment of diabetic rats restored the inositol content of glomeruli to control values without altering the magnitude of hyperglycemia, and did not prevent activation of glomerular protein kinase C. By contrast, treatment with insulin restored glomerular inositol content, corrected the hyperglycemia and prevented activation of protein kinase $C$.

In the present study the effects of high media glucose concentration on the subcellular distribution of protein kinase $\mathrm{C}$ incubated in vitro were transient. The factors responsible for this peak-decline response pattern of protein kinase $C$ in vitro are uncertain. In vitro depletion of diacylglycerol, of critical subcellular pools of phospholipids, fatty acids, or other moieties that may participate in protein kinase $\mathrm{C}$ activation can 
not be excluded. Notably, in a cultured cell system of bovine retinal epithelial cells, where a more complex media was employed, a high media glucose concentration produced a sustained activation of protein kinase $C(42)$. Conversely, it is quite possible that hyperglycemia per se is not the sole mediator of the protein kinase $\mathrm{C}$ activation observed in glomeruli isolated from diabetic rats. Clearly, an array of hormonal and metabolic changes occur in the diabetic state that may be involved in the in vivo activation of protein kinase $C$ in the glomeruli.

Studies in glomeruli from control rats also demonstrated that high media glucose concentrations increased the accumulation of labeled diacylglycerol, as assessed by enhanced incorporation of labeled myristate into diacylglycerol. The increase in labeled diacylglycerol occurred over the same range of glucose concentrations which was found to activate protein kinase $C$. This is consistent with the possibility that enhanced diacylglycerol production may mediate activation of protein kinase $C$ seen in response to glucose.

Studies in pancreatic islets (43-47) and adipose tissue (36) have demonstrated that glucose can increase diacylglycerol production and stimulate $\mathrm{Ca}^{2+}$ and phospholipid dependent phosphorylation both by stimulating de novo synthesis of diacylglycerol $(43,44,48)$ and by enhancing phospholipase $C$ induced hydrolysis of inositol phospholipids $(45,47)$. With respect to the phospholipase $C$ pathway, the results of the present study demonstrate that glucose does not increase diacylglycerol production in glomeruli by stimulating hydrolysis of inositol phospholipids (PI, PIP, or PIP ${ }_{2}$ ). This is implied by the observation that glucose does not increase the production of inositol phosphates in glomeruli which were prelabeled with $\left[{ }^{3} \mathrm{H}\right]$ inositol. By contrast, angiotensin II, a known activator of phospholipase $\mathrm{C}$ in glomeruli, increased inositol phosphate production twofold under the same conditions of incubation. Thus, inositol phospholipid hydrolysis was not implicated in the action of glucose. However, our studies do not exclude an effect of glucose to enhance phospholipase $\mathrm{C}$-mediated hydrolysis of phosphatidylcholine (49), or of the recently described phosphatidylinositol-glycan moiety $(28,50)$. With respect to de novo diacylglycerol production, glucose may enhance glycerol 3-phosphate production via the glycolytic pathway (43, $44,48)$. Glycerol 3-phosphate is converted to phosphatidic acid by glycerol 3-phosphate acyltransferase and phosphatidic acid is then further hydrolyzed to diacylglycerol. Accordingly, an increased flux of glucose through this pathway would be expected to increase diacylglycerol production. Additional studies are required to determine the role of de novo diacylglycerol synthesis in mediating actions of glucose on glomerular protein kinase $C$.

Glucose has been shown to increase cytosolic $\mathrm{Ca}^{2+}$ in pancreatic islets (51) and recent evidence suggests that an increase in cytosolic $\mathrm{Ca}^{2+}$ alone may be sufficient to trigger protein kinase $C$ activation (52). The possibility that glucose induced increases in cytosolic $\mathrm{Ca}^{2+}$ may contribute to the observed activation of protein kinase $C$ remains to be examined.

Whatever, the mechanism by which protein kinase $C$ is activated in glomeruli of diabetic rats, this finding is of considerable interest and potential importance. Numerous previous studies have demonstrated an association between activation of protein kinase $C$ and enhanced cell growth (53-55). Renal hypertrophy and hyperplasia are early events which occur within the first few days after induction of diabetes (56) and may contribute to the early increase in glomerular filtration rate (57). Studies of remnant kidney after subtotal nephrectomy (58) and in cultured glomerular epithelial cells, stimulated to divide with leukotrienes (59) have also suggested a role for protein kinase $\mathrm{C}$ in the control of renal growth. Furthermore, diacylglycerol and protein kinase $C$ have been implicated in both the mediation and modulation of prostaglandin synthesis in intact glomeruli and cultured mesangial cells $(60-62)$. The synthesis of vasodilatory prostaglandins is increased by $1-2$ wk in glomeruli from diabetic rats $(17,25$, 63-65) and remains increased in moderately hyperglycemic rats in association with increased glomerular filtration rate (GFR). Several studies (56) conducted with inhibitors of prostaglandin synthesis have linked enhanced production of vasodilatory prostaglandin to increases in GFR $(17,65-69)$. The present results thus raise the possibility that an increase in the state of activation of protein kinase $C$ in diabetic glomeruli may contribute to the increases in renal growth and GFR, which are characteristic of early diabetes.

\section{Acknowledgments}

The authors are indebted to Karen Thornburg, Myung Hee Jeong, and Philip Lauro for excellent technical assistance and to Florence Flick for typing the manuscript.

This work was supported by National Institutes of Health grant 5-R01-DK 34592. The authors would like to thank Pfizer Inc. Groton, $\mathrm{CT}$, for providing the sorbinil used in this study.

\section{References}

1. Gabbay, K. H. 1973. The sorbitol pathway and the complications of diabetes. N. Engl. J. Med. 288:831-838.

2. Green, D. A., S. A. Lattimer, and A. A. F. Sima. 1987. Sorbitol, phosphoinositides and sodium potassium ATP ase in the pathogenesis of diabetic complications. N. Engl. J. Med. 3116:599-606.

3. Beyer, T. A., and N. J. Hutson. 1986. Introduction: Evidence for the role of the polyol pathway in the pathophysiology of diabetic complications. Metab. Clin. Exp. 35:1-3.

4. Winegrad, A. I. 1987. Does a common mechanism induce the diverse complications of diabetes? Diabetes. 36:396-406.

5. Beyer-Mears, A., L. Ku, and M. P. Cohen. 1984. Glomerular polyol accumulation in diabetes and its prevention by oral sorbinil. Diabetes. 33:604-607.

6. Cohen, M. P. 1986. Aldose reductase, glomerular metabolism and diabetic nephropathy. Metab. Clin. Exp. 35:55-59.

7. Beyer-Mears, A. 1986. The polyol pathway, sorbinil and renal dysfunction. Metab. Clin. Exp. 35:46-54.

8. Goldfarb, S., D. A. Simmins, and E. F. O. Kern. 1986. Amelioration of glomerular hyperfiltration in acute experimental diabetes mellitus by dietary myo-inositol supplementation and aldose reductase inhibition. Trans. Assoc. Am. Phys. 99:67-72.

9. Fukushi, S., L. Merola, and J. H. Kinoshita. 1980. Altering the course of cataracts in diabetic rats. Invest. Ophthalmol. Vis. Sci. 19:313-315.

10. Gillon, K. R. W., J. N. Hawthorne, and D. R. Tomlinson. 1983. Myo-inositol and sorbitol metabolism in relation to peripheral nerve function in experimental diabetes in the rat: the effect of aldose reductase inhibition. Diabetologia. 25:365-371.

11. Greene, D. A., and S. A. Lattimer. 1987. Altered sorbitol and myo-inositol metabolism as the basis for defective protein kinase $\mathrm{C}$ and $(\mathrm{Na}+, \mathrm{K}+)$-ATPase regulation in diabetic neuropathy. Ann. $N Y$ Acad. Sci. 334-339.

12. Greene, D. A., and S. A. Lattimer. 1986. Protein kinase C agonists acutely normalize decreased ouabain-inhibitable respiration 
in diabetic rabbit nerve, implication for $(\mathrm{Na}+, \mathrm{K}+)$-ATPase regulation and diabetic complications. Diabetes. 35:242-245.

13. Berti-Mattera, L. N., R. G. Peterson, and J. Eichberg. 1986. Insulin reverses enhanced incorporation of ${ }^{32} \mathrm{P}$ into polyphosphoinositides in peripheral nerve of the streptozotocin diabetic rat. J. Neurochem. 47:1932-1935.

14. Schrama, L. H., L. N. Berti-Mattera, and J. Eichberg. 1987. Altered protein phosphorylation in sciatic nerve from rats with streptozotocin induced diabetes. Diabetes. 36:1254-1260.

15. Patel, D. G. 1983. Rate of insulin infusion with a mini-pump required to maintain normoglycemia in diabetic rats. Proc. Soc. Exp. Biol. Med. 172:74-78.

16. Raabo E., and T. C. Terkildsen. 1960. On the enzymatic determination of blood glucose. Scand. J. Clin. Lab. Invest. 12:402-407.

17. Craven, P. A., M. A. Caines, and F. R. DeRubertis. 1987. Sequential alterations in glomerular prostaglandin and thromboxane synthesis in diabetic rats. Relationship to the hyperfiltration of early diabetes. Metab. Clin. Exp. 36:95-103.

18. Cohen, P., M. J. Brockman, A. Veckley, J. W. W. Lisman, and A. Derksen. 1971. Quantification of human platelet inositides and the influence of ionic environment on the incorporation of $\left[{ }^{32} \mathrm{P}\right]$ orthophosphate. J. Clin. Invest. 50:762-772.

19. Craven, P. A., R. Briggs, and F. R. DeRubertis. 1980. Calcium dependent action of osmolality on adenosine $3^{\prime} 5^{\prime}$ monophosphate accumulation in rat renal inner medulla. Evidence for a relationship to calcium responsive arachidonate release and prostaglandin synthesis. J. Clin. Invest. 65:529-542.

20. Irvine, R. F. A., J. Letcher, and R. M. C. Dawson. 1984. Phosphatidylinositol-4,5-bisphosphate phosphodiesterase and phosphomonoesterase activities of rat brain. Biochem. J. 218:170-185.

21. Downes, C. P., and R. H. Michell. 1981. The polyphosphoinositide phosphodiesterase of erythrocyte membranes. Biochem. J. 198:133-140.

22. Kraft, A. S., and W. B. Anderson. 1983. Phorbol esters increase the amount of $\mathrm{Ca}^{2+}$ phospholipid dependent protein kinase associated with the plasma membrane. Nature (Lond.). 301:621-623.

23. Kraft, A. S., W. B. Anderson, H. C. Cooper, and J. J. Sando. 1982. Decrease in cytosolic $\mathrm{Ca}^{2+}$ phospholipid dependent protein kinase activity following phorbol ester treatment of EL 4 thymoma cells. J. Biol. Chem. 257:13193-13196.

24. Dethy, J. M., B. Callaert-Deveen, M. Janssens, and A. Lenaers. 1984. Determination of sorbitol and galactitol at the nanogram level in biological samples by high-performance liquid chromatography. Anal. Biochem. 143:119-124.

25. Craven, P. A., M. C. Patterson, and F. R. DeRubertis. 1988. Role of enhanced arachidonate availability through the phospholipase $A_{2}$ pathway in the mediation of increased prostaglandin synthesis by glomeruli from diabetic rats. Diabetes. 37:429-435.

26. Craven, P. A., J. Pfanstiel, and F. R. DeRubertis. 1987. Role of activation of protein kinase $\mathrm{C}$ in the stimulation of colonic epithelial proliferation and reactive oxygen formation by bile acids. J. Clin. Invest. 79:532-541.

27. Craven, P. A., and F. R. DeRubertis. 1988. Sorbinil suppresses glomerular prostaglandin production and reduces hyperfiltration in the streptozotocin diabetic rat. Clin. Res. 36:517. (Abstr.)

28. Saltiel, A. R., P. Sherline, and J. A. Fox. 1987. Insulin stimulated diacylglycerol production results from the hydrolysis of a novel phosphatidylinositol glycan. J. Biol. Chem. 262:1116-1121.

29. Greene, D. A., P. V. DeJesus, and A. I. Winegrad. 1975. Effects of insulin and dietary myo-inositol on impaired peripheral motor nerve conduction velocity in acute streptozotocin diabetes. J. Clin. Invest. 55:1326-1336.

30. Kim, J., B. Agranoff, T. Ueda, and D. A. Greene. 1988. Dietary myo-inositol prevents decreased native protein kinase $\mathrm{C}$ activity in diabetic rat nerve. Clin. Res. 36:586a. (Abstr.)

31. Gillon, K. R. W., and J. N. Hawthorne. 1983. Transport of myo-inositol into endoneurial preparations of sciatic nerve from normal and streptozotocin diabetic rats. Biochem. J. 210:775-781.
32. Cohen, M. P., and H. Klepser. 1985. Binding of an aldose reductase inhibitor to renal glomeruli. Biochem. Biophys. Res. Commun. 129:530-535.

33. Yoshida, Y., F. L. Huang, H. Nakabayashi, and K. P. Huang. 1988. Tissue distribution and developmental expression of protein kinase C isozymes. J. Biol. Chem. 263:9868-9873.

34. Ramsdell, J. S., G. R. Pettit, and A. H. Tashjian, Jr. 1986. Three activators of protein kinase $\mathrm{C}$, bryostatins, dioleins and phorbol esters show differing specificities of action on $\mathrm{GH}_{4}$ pituitary cells. $J$. Biol. Chem. 261:17073-17080.

35. Kolesnick, R. N., and A. E. Paley. 1987. 1,2 Diacylglycerols and phorbol esters stimulate phosphatidylcholine metabolism in $\mathbf{G H}_{3}$ pituitary cells. J. Biol. Chem. 262:9204-9210.

36. Kreutter, D., A. B. Caldwell, and M. J. Morin. 1985. Dissociation of protein kinase $C$ activation from phorbol ester-induced maturation of HL-60 leukemia cells. J. Biol. Chem. 260:5979-5984.

37. Ballester, R., and O. M. Rosen. 1985. Fate of immunoprecipitable protein kinase $\mathrm{C}$ in $\mathrm{GH}_{3}$ cells treated with phorbol 12-myristate 13-acetate. J. Biol. Chem. 260:15194-15199.

38. Donnelly, T. E., Jr., D. F. Birt, R. Sittler, C. L. Anderson, M. Choe, and A. Julius. 1987. Dietary fat regulation of the association of protein kinase $\mathrm{C}$ activity with epidermal cell membranes. Carcinogenesis. 8:1867-1870.

39. Nagao, S. M. Seishima, S. Mori, and Y. Nozawa. 1988. Increased protein kinase $C$ activity in fibroblast membranes from psoriatic patients. J. Invest. Dermatol. 90:406-408.

40. Hise, M. K., and P. S. Mehta. 1988. Characterization of and localization of calcium phospholipid-dependent protein kinase $\mathrm{C}$ during diabetic renal growth. Endocrinology. 123:1553-1558.

41. Wolfman, A., and I. G. Macara. 1988. Elevated levels of diacylglycerol and decreased phorbol ester sensitivity in ras transformed fibroblasts. Nature (Lond.). 325:359-361.

42. Lee, T. S., L. C. MacGregor, S. Fluharty, and G. L. King. 1989. Differential regulation of protein kinase $\mathrm{C}$ and $(\mathrm{Na}, \mathrm{K})$-adenosine triphosphatase activities by elevated glucose levels in retinal capillary endothelial cells. J. Clin. Invest. 83:90-94.

43. Peter-Riesch, B., M. Fathi, W. Schlegel, and C. B. Wollheim. 1988. Glucose and carbachol generate 1,2-diacylglycerols by different mechanisms in pancreatic islets. J. Clin. Invest. 81:1154-1161.

44. Farese, R. V., P. E. DiMarco, D. E. Barnes, M. A. Sabis, R. E. Larson, J. S. Davis, and A. D. Morrison. 1986. Rapid glucose-dependent increases in phosphatidic acid and phosphoinositides in rat pancreatic islets. Endocrinology. 118:1498-1503.

45. Dunlop, M. E., and R. G. Larkins. 1984. Activity of endogenous phospholipase $C$ and phospholipase $A_{2}$ in glucose stimulated pancreatic islets. Biochem. Biophys. Res. Commun. 120:820-824.

46. Dunlop, M. E., and R. G. Larkins. 1986. Glucose induced phospholipid dependent protein phosphorylation in neonatal rat islets. Arch. Biochem. Biophys. 248:562-569.

47. Wolf, B. A., J. Florholmen, J. Turk, and M. L. McDaniel. 1988. Studies of the $\mathrm{Ca}^{2+}$ requirements for glucose and carbachol-induced augmentation of inositol trisphosphate and inositol tetrakisphosphate accumulation in digitonin permeabilized islets. Evidence for a glucose recognition site in insulin secretion. J. Biol. Chem. 263:3565-3575.

48. Farese, R. V., R. V. Farese, Jr., M. A. Sabir, R. E. Larson, W. L. Trudeau III, and D. Barnes. 1984. The mechanism of activation by insulin of phospholipid metabolism in rat adipose tissue, requirement for protein synthesis and a carbohydrate source and relationship to activation of pyruvate dehydrogenase. Diabetes. 33:648-655.

49. Besterman, J. M., V. Duronio, and P. Cuatrescasas. 1986. Rapid formation of diacylglycerol from phosphatidylcholine. A pathway for generation of a second messenger. Proc. Natl. Acad. Sci. USA. 83:6785-6789.

50. Fox, J. A., N. M. Soliz, and A. R. Saltiel. 1987. Purification of a phosphatidylinositol-glycan specific phospholipase $\mathrm{C}$ from liver plasma membrane: a possible target of insulin action. Proc. Natl. Acad. Sci. USA. 84:2663-2667.

51. Nilsson, T., P. Arkhammer, and P. Berggren. 1988. Dual effects 
of glucose on cytoplasmic free $\mathrm{Ca}^{2+}$ concentration and insulin release reflects the B-cell being deprived of fuel. Biochem. Biophys. Res. Commun. 153:984-991.

52. Ho, A. K., T. P. Thomas, C. L. Chik, W. B. Anderson, and D. C. Klein. 1988. Protein kinase C: subcellular redistribution by increased $\mathrm{Ca}^{2+}$ influx. J. Biol. Chem. 263:9292-9297.

53. Rozengurt, E., A. Rodriquez-Pena, and J. Sinnett-Smith. 1985 Signalling mitogenesis in $3 \mathrm{~T} 3$ cells: role of $\mathrm{Ca}^{2+}$ sensitive phospholipid dependent protein kinase. In Ciba Foundation Symposium, 116, Growth Factors in Biology and Medicine. 766-860.

54. Berridge, M. J. 1986. Growth factors, oncogenes and inositol lipids. Cancer Surv. 5:413-430.

55. Anderson, W. P., A. Estival, H. Tapivaara, and R. Gopalkrishma. 1985. Altered subcellular distribution of protein kinase $C$ (a phorbol ester receptor). Possible role in tumor promotion and the regulation of cell growth. Relationship to changes in adenylate cyclase activity. Adv. Cyclic Nucl. Protein Phosphor. Res. 19:287-306.

56. Seyer-Hansen, K. 1983. Renal hypertrophy in experimental diabetes mellitus. Kidney Int. 23:643-646.

57. Mogensen, C. E., and M. J. F. Andersen. 1975. Increased kidney size and glomerular filtration rate in untreated juvenile diabetes: normalization by insulin treatment. Diabetologia. 11:221-224.

58. Carmelo, C., P. Tsai, K. Okada, and R. W. Schrier. 1988. Potential role of protein kinase $\mathrm{C}$ in compensatory kidney growth. Clin. Res. 36:516. (Abstr.)

59. Band, L., G. Cherqui, J. Perez, E. J. Cragoe, Jr., and R. Ardaillou. 1988. Role of protein kinase $\mathrm{C}$ (PKC) and $\mathrm{Na}+/ \mathrm{H}+$ exchange in the stimulation of glomerular epithelial cell proliferation by leukotrienes (LT) C4 and D4. Kidney Int. 33:254a. (Abstr.)

60. Craven, P. A., M. C. Patterson, and F. R. DeRubertis. 1987. Role for protein kinase $\mathrm{C}$ in $\mathrm{A} 23187$ induced glomerular arachidonate release and $\mathrm{PGE}_{2}$ production. Biochem. Biophys. Res. Commun. 149:658-664.
61. Craven, P. A., M. C. Patterson, and F. R. DeRubertis. 1988 Role for protein kinase $C$ in the modulation of glomerular $\mathrm{PGE}_{2}$ production by angiotensin II. Biochem. Biophys. Res. Commun. 152:1481-1489.

62. Pfeilschifter, J., and C. Bauer. 1986. Role of phospholipase C and protein kinase $C$ in vasoconstrictor-induced prostaglandin synthesis in cultured rat renal mesangial cells. Biochem. J. 236:289-294.

63. Kreisberg, J. I., and P. Y. Patel. 1983. The effects of insulin, glucose and diabetes on prostaglandin production by rat kidney glomeruli and cultured glomerular mesangial cells. Prostaglandins Leukotrienes Med. 11:431-442.

64. Schambelan, M., S. Blake, J. Sreer, M. Bens, M.-P. Nivez, and F. Wahbe. 1985. Increased prostaglandin production by glomeruli isolated from rats with streptozotocin-induced diabetes mellitus. J. Clin. Invest. 75:404-412.

65. Kirschenbaum, M. A., and A. Chaudhari. 1986. Effect of experimental diabetes on glomerular filtration rate and glomerular prostanoid production in the rat. Miner. Electrolyte Metab. 12:353-355.

66. Craven, P. A., and F. R. DeRubertis. 1988. Role for glomerular prostaglandin and thromboxane production in the mediation of alterations in glomerular filtration rate in streptozotocin diabetic rats. Clin. Res. 36:516a. (Abstr.)

67. Jensen, P. K., K. Steven, H. Blaehr, J. S. Christiansen, and H. Parving. 1986. Effects of indomethacin on glomerular hemodynamics in experimental diabetes. Kidney Int. 29:490-495.

68. Moel, D. I., R. L. Safirstein, R. C. McEvoy, and W. Hsueh. 1987. Effect of aspirin on experimental diabetic nephropathy. J. Lab. Clin. Med. 110:300-307.

69. Esmatjes, E., M. R. Fernandez, I. Halperin, J. Camps, J. Gaya, V. Arroyo, F. Rivera, and D. Figuerola. 1985. Renal hemodynamic abnormalities in patients with short term insulin-dependent diabetes mellitus: role of renal prostaglandins. J. Clin. Endocrinol. Metab. 60:1231-1236. 